\title{
Stand Structure and Growth Pattern of Deodar (Cedrus deodara Roxb. Loud) Forests of Western Himalaya (India)
}

\author{
V.C. Prahlad* \\ Department of Silviculture and Agro-forestry, College of Horticulture and Forestry, Jhalawar \\ (Agriculture University, Kota) 326023 (Raj.), India \\ Corresponding author
}

\section{Keywords \\ Basal area, Green felling, Growing stock, Periodic blocks, Stand structure, Stem density}

\section{Article Info}

Accepted: 15 June 2018 Available Online: 10 July 2018

\section{A B S T R A C T}

Study on structure and growing Stock of deodar stands of Himalayan forests under existing mute silvical treatments due to imposed ban on green felling revealed that stem density (N/ha) varied in increasing order 277.8, 390,484.4 and 816.7 under PBI, II, III and IV approves the principle of allotment of PBs as per the crop age. Regenerated block PBIV, obviously supports more density. Whereas, diameter at breast height $(\mathrm{cm})$ was found increasing from $21.11 \mathrm{~cm}$ in PBIV $30.01 \mathrm{~cm}$ in PBIII $44.64 \mathrm{~cm}$ in PBII and $57.37 \mathrm{~cm}$ in PBI and maximum mean diameter of the site reported $40.34 \mathrm{~cm}$ in Cheog $\left(\mathrm{S}_{3}\right)$. Diameter performance shows smaller diameter trees with higher stem density in PBIV and higher diameter trees in PBI with less stocking. Good soil depth and less disturbances compared to other sites be added substantiation for significant diameter performance at $S_{3}$. Mean tree height showed significant variation with $26.67 \mathrm{~m}$ at $S_{3}$ and $31.88 \mathrm{~m}$ in PBI. Tree height differentiation indicates the level of competition with neighbor resulting differentiated use of vertical space as well as varying pattern of crown size formation with respect to density for light requirements in these stands. Trees on good site quality grow taller than on poor ones. Highest mean basal area $70.95 \mathrm{~m}^{2} / \mathrm{ha}$ obtained in PBI and lowest $34.02 \mathrm{~m}^{2} / \mathrm{ha}$ in PBIV and at site level highest $56.38 \mathrm{~m}^{2} / \mathrm{ha}$ at $\mathrm{S}_{3}$ and lowest $44.62 \mathrm{~m}^{2} / \mathrm{ha}$ at Habban $\left(\mathrm{S}_{1}\right)$ respectively. Form factor performance showed significant variation both at site and their interaction level with minimum 0.219 taper at Chail $\left(S_{2}\right)$ and interaction level maximum 0.363 taper at $S_{1} B_{2}$ and minimum 0.207 at $S_{2} B_{2}$. The total growing stock (stem volume/ha) showed significant variation for PBs only where PBI $\left(640.44 \mathrm{~m}^{3} / \mathrm{ha}\right)>\operatorname{PBII}(492.24$ $\left.\mathrm{m}^{3} / \mathrm{ha}\right)>$ PBIII $\left(381.88 \mathrm{~m}^{3} / \mathrm{ha}\right)>$ PBIV $\left(205.79 \mathrm{~m}^{3} / \mathrm{ha}\right)$ respectively.

\section{Introduction}

Stand structure has been defined as the horizontal and vertical distribution of components of a forest stand including the height, diameter, crown layers and stems of trees, shrubs, herbaceous understorey, snags and coarse woody debris (Helms1998). Further, the composition and spatial variability of forest structure is a major focus of forest ecological study as it relates to functional attributes as basal area increment in young 
trees increases until their maximum usable growing space is reached (Assmann, 1970). Natural and manmade interventions alter the forest structure and composition, thus knowledge of stand dynamics supports decision making. Ishi et al., (2004) reported that simplification of stand structure diminish ecosystem functions and biodiversity services. Stand structure has been defined as the horizontal and vertical distribution of components of a forest stand including the height, diameter, crown layers and stems of trees, shrubs, herbaceous understorey, snags and coarse woody debris (Helms 1998). However, ecosystem functions of biodiversity can be enhanced by managing forests for increased structural complexity. Silviculture interventions directed at the production of timber crops is pointless without the crops can be harvested and utilized profitably. Improperly managed forest forms too dense or too sparse stand condition results detrimental forest growth. To achieve the sustainability of forest existence of normal forest is a prerequisite (Avery and Burkhart 1983).

The Indian Himalayan region occupies a special place in the mountain ecosystems of the world. Considering this India's National Action Plan on Climate Change (GOI 2008) has made special provision of a National mission for Sustaining Himalayan Ecosystem. Himachal Pradesh (H.P) is a mountainous state consequently its climate is more congenial to forests. The forest vegetation in the Himalayan region ranges from tropical dry deciduous forests in the foothills to alpine meadows above timberline (Champion and Seth 1968). Physiographic zone-wise, the Western Himalayan region in the country alone contributes $1008 \mathrm{mi} \mathrm{cu} \mathrm{m}$ of Growing stock inside forest area out of the total 4173 mi cu m of which $325.36 \mathrm{mi} \mathrm{cu} \mathrm{m}$ volume of growing stock decreased between the year 2011 to 2013 is almost equivalent to the growing stock in the forests of Himachal Pradesh state (FSI 2013).
Continued deforestation and forest degradation (Joshi et al., 2001) perceived as evidence of management and policy failures to provide sustainable timber supply and environmental protection ban on green felling has been imposed in the state after 1985, and then silvicultural treatments and other stand management practices are defunct and no information available on impact of this ban on deodar forest's structure and productivity. As a result, deodar (Cedrus deodara (Roxb.) Loud) being one of the most important naturally durable western Himalayas managed commercial timber species under uniform system or its modification like Punjab shelterwood system, selection or its modified form (Anon 1985) stand treatments are standstill. More so, in absence of forest extraction and mute silvical plans employing precise stand treatments to smoothened out irregularity should receive attention. This, investigation is an attempt in describing structural and growth aspects of deodar forests viz., density (trees/ ha), total basal area $\left(\mathrm{m}^{2} / \mathrm{ha}\right)$ and growing stock $\left(\mathrm{m}^{3} / \mathrm{ha}\right)$.

\section{Materials and Methods}

\section{Study area and methodology}

\section{Location and stand selection}

This study was undertaken in the year 2010-13 in selected natural pure deodar stands of Cedrus deodara to assess the density and basal cover pattern and its distribution in different diameter class under different site conditions in parts of temperate forests from western Himalayan regions of Himachal Pradesh (India). For this, three locations, Habban $\left(\mathrm{S}_{1}\right)$, Chail $\left(\mathrm{S}_{2}\right)$ and Cheog $\left(\mathrm{S}_{3}\right)$ forest range/administrative units were selected (Table 1). At each location randomly three replication with plot size 0.1 ha $(20 \times 50 \mathrm{~m})$ in four Periodic blocks $(\mathrm{PBs})$ or erstwhile managed conventional management units (PBI $\left(\mathrm{B}_{1}\right)$, PBII $\left(\mathrm{B}_{2}\right)$, PBIII $\left(\mathrm{B}_{3}\right)$ and PBIV $\left(\mathrm{B}_{4}\right)$ were laid out (Table 1). 


\section{Stand measurement}

Partial enumeration was carried out for stand growth assessment according to the standard forest mensuration practices. After thorough inspection, trees falling under each site were enumerated to determine the stand density as number of plants per hectare and were arranged in diameter classes of $10 \mathrm{~cm}$ classwidth. In all the plots, the stem diameter $(\mathrm{cm})$ at breast height (1.37 $\mathrm{m}$ above ground level) was measured with the help of tree caliper. Basal area refers to the cross sectional area of the stems and calculated by using following relation:

$$
\text { Basal Area }=\pi \times \frac{\mathrm{d}^{\mathrm{x}}}{4}
$$

Where, d Diameter (cm). Further, Total Basal Area was assessed by considering the sum of the product of number of trees to the cross sectional area of the stems in each diameter class. The height of the tree was measured with the help of Spiegel Relaskop and is expressed in meters. The form factor was calculated separately for each diameter class using the formula given by Bitterlich (1984). $\mathrm{FF}=\frac{2}{3} \times \frac{\mathrm{h} 1}{\mathrm{~h}}$

Where, ff - Form factor, h1 Height (m) at which diameter is half of the $\mathrm{dbh}, \mathrm{h}$ - Total height (m) of the tree. Growing stock or Volume of standing trees was calculated by Pressler's (1865) formula $V=\frac{\pi d^{2}}{4} \times h \times f f \times \frac{1}{100 \times 100}$ Where, V-Volume $\left(\mathrm{m}^{3}\right), \mathrm{d}$-Diameter at breast height $(\mathrm{cm}), \mathrm{h}$-Tree height $(\mathrm{m})$ and ff-Form factor. and expressed in cubic meters. Further, the volume per hectare was calculated by multiplying the mean volume with number of trees in respective diameter classes per hectare.

\section{Results and Discussion}

The site and periodic block wise stem density (N/ha) showed (Table 2) the significant variation in different periodic block level when compared among sites which varied in increasing order $277.8,390,484.4$ and 816.7
N/ha under PBI, II, III and IV respectively. PBIV stands significantly differ from other three $\mathrm{PBs}$ but, there is no significant variation among PBIII and PBII, PBII and PBI. The mean of stem density among sites were insignificant with values $453.3,465$ and 558.3 $\mathrm{N} / \mathrm{ha}$ in $\mathrm{S}_{3}, \mathrm{~S}_{1}$ and $\mathrm{S}_{2}$ respectively. The diameter at breast height $(\mathrm{cm})$ was found increasing from $21.11 \mathrm{~cm}$ in PBIV 30.01 in PB III $44.64 \mathrm{~cm}$ in PBII and $57.37 \mathrm{~cm}$ in PBI. The mean diameter of the site was insignificant; however, the maximum mean diameter reported was $40.34 \mathrm{~cm}$ in $S_{3}$. With reference to mean diameter of the trees, the interaction between site and periodic block was also found significantly different.

Further, mean tree height (m) shown significant variation for different site and $\mathrm{PBs}$ with maximum value at $S_{3}(26.67 \mathrm{~m})$ and in PBI $(31.88 \mathrm{~m})$. The performance at site levels shows that $S_{3}$ varies significantly with other two sites in an order $S_{3}>S_{1}>S_{2}$ but, found no significant variation between $S_{2}$ and $S_{1}$. In contrast all PBs differ significantly with each other. In current study highest $\left(70.95 \mathrm{~m}^{2} / \mathrm{ha}\right)$ mean basal area/ha obtained in PBI followed by PBII $\left(61.74 \mathrm{~m}^{2} / \mathrm{ha}\right)$, PBIII $\left(45.76 \mathrm{~m}^{2} / \mathrm{ha}\right)$ and PBIV $\left(34.02 \mathrm{~m}^{2} / \mathrm{ha}\right)$ respectively. Further, PBII varied significantly with PBIII but there was no significant variation between PBI and PBII and PBIII and PBIV. However, at site level highest basal area/ha was reported at $S_{3}$ $\left(56.38 \mathrm{~m}^{2} / \mathrm{ha}\right)$ followed by $\mathrm{S}_{2}\left(58.35 \mathrm{~m}^{2} / \mathrm{ha}\right)$ and lowest at $S_{1}\left(44.62 \mathrm{~m}^{2} / \mathrm{ha}\right.$ ) (Table 2).

Form factor performance showed significant variation both at site and their interaction level with minimum taper at site level $S_{2}(0.219)$. The interaction level for the said parameter between site and PBs showed the maximum taper at $S_{1} B_{2}(0.363)$ and minimum at $S_{2} B_{2}$ (0.207). Whereas, $\mathrm{H}_{1}$ found varying significantly at site, $\mathrm{PBs}$ and their interaction levels. Among the sites mean $\mathrm{H}_{1}$ was found highest at $\mathrm{S}_{1}(12.38 \mathrm{~m})$. However, the mean $\mathrm{H}_{1}$ 
values were found to be consistently increasing with values $6.90 \mathrm{~m}, 9.05 \mathrm{~m}, 11.19 \mathrm{~m}$ and $13.03 \mathrm{~m}$ at PBIV, PBIII, PBII and PBI respectively. The total growing stock (stem volume/ha) showed significant variation for PBs only. The stem volume performance was found to be in descending order where PBI $\left(640.44 \mathrm{~m}^{3} / \mathrm{ha}\right)>$ PBII $\left(492.24 \mathrm{~m}^{3} / \mathrm{ha}\right)>$ PBIII $\left(381.88 \mathrm{~m}^{3} / \mathrm{ha}\right)>$ PBIV $\left(205.79 \mathrm{~m}^{3} / \mathrm{ha}\right)$ respectively (Figure 1). Except PBI and PBII and PBII and PBIII remaining PBs show significant variation among each other.

Table.1 Location and details of the study sites

\begin{tabular}{|c|c|c|c|c|c|c|}
\hline $\begin{array}{l}\text { Locality } \\
\text { (District) }\end{array}$ & $\begin{array}{c}\text { Forest } \\
\text { Division }\end{array}$ & $\begin{array}{c}\text { Altitude } \\
(\mathbf{m})\end{array}$ & $\begin{array}{c}\text { Rainfall } \\
\text { (about } \\
\text { mm/yr) }\end{array}$ & $\begin{array}{c}\text { Temperature } \\
\left({ }^{\circ} \mathbf{C}\right)\end{array}$ & $\begin{array}{c}\text { Parent } \\
\text { material }\end{array}$ & Coordinates \\
\hline $\begin{array}{l}\text { Habban- } \\
\left(\mathbf{S}_{1}\right) \\
\text { (Sirmour) }\end{array}$ & $\begin{array}{l}\text { Rajgarh } \\
\text { Forest } \\
\text { Division }\end{array}$ & $\begin{array}{l}1750- \\
2000\end{array}$ & 1500 & 42 to below 0 & $\begin{array}{l}\text { Slates, } \\
\text { schist and } \\
\text { limestone. }\end{array}$ & 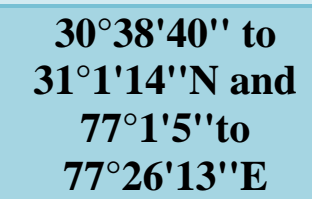 \\
\hline $\begin{array}{c}\text { Chail- } \\
\left(\mathbf{S}_{2}\right) \\
\text { (Shimla) }\end{array}$ & $\begin{array}{c}\text { Shimla } \\
\text { Wildlife } \\
\text { Forest } \\
\text { Division }\end{array}$ & $\begin{array}{l}1860- \\
2100\end{array}$ & 1050 & 40 to -4 & $\begin{array}{c}\text { Shale, } \\
\text { schist, } \\
\text { slate and } \\
\text { quartzite. }\end{array}$ & $\begin{array}{c}30^{\circ} 53 ' 36^{\prime \prime} \text { and } \\
31^{\circ} 00^{\prime} 42^{\prime \prime} \text { N and } \\
77^{\circ} 07^{\prime} 20^{\prime \prime} \text { to } \\
77^{\circ} 16^{\prime} 44^{\prime \prime} \mathrm{E}\end{array}$ \\
\hline $\begin{array}{c}\text { Cheog - } \\
\left(\mathbf{S}_{3}\right) \\
\text { (Shimla) }\end{array}$ & $\begin{array}{c}\text { Theog } \\
\text { Forest } \\
\text { Division }\end{array}$ & $\begin{array}{l}2020- \\
2180\end{array}$ & 1250 & 40 to below 0 & $\begin{array}{c}\text { Shale, silt } \\
\text { stone, } \\
\text { quartzite }\end{array}$ & $\begin{array}{c}30^{\circ} 56^{\prime} 55^{\prime \prime} \text { to } \\
31^{\circ} 17^{\prime} 50^{\prime \prime} \mathrm{N} \text { and } \\
77^{\circ} 16^{\prime} 10^{\prime \prime} \text { to } \\
77^{\circ} 37^{\prime} 32^{\prime \prime} \mathrm{E}\end{array}$ \\
\hline
\end{tabular}

Table.2 Stem desity, stand growth and growing stock details at site and PBs level

\begin{tabular}{|c|c|c|c|c|c|c|c|}
\hline $\begin{array}{c}\text { Sites and } \\
\text { Periodic } \\
\text { Blocks (P.Bs) }\end{array}$ & N/ha & DBH $(\mathbf{c m})$ & $\mathbf{H t}(\mathbf{m})$ & $\mathbf{h}_{\mathbf{1}(\mathbf{m})}$ & $\mathbf{T B A}\left(\mathbf{m}^{\mathbf{2} / \mathbf{h a})}\right.$ & $\mathbf{f f}$ & $\mathbf{G S}\left(\mathbf{m}^{\mathbf{3} / \mathbf{h a})}\right.$ \\
\hline Habban $\left(\mathrm{S}_{1}\right)$ & 465 & 37.4 & 23.62 & 12.38 & 44.62 & 0.343 & 465.89 \\
\hline Chail $\left(\mathbf{S}_{2}\right)$ & 558.3 & 37.11 & 23.34 & 7.61 & 58.35 & 0.219 & 342.98 \\
\hline Cheog $\left(\mathbf{S}_{3}\right)$ & 453.3 & 40.34 & 26.67 & 10.13 & 56.38 & 0.258 & 481.39 \\
\hline PB-I & 277.8 & 57.37 & 31.88 & 13.03 & 70.95 & 0.272 & 640.44 \\
\hline PB-II & 390 & 44.64 & 27.75 & 11.19 & 61.74 & 0.263 & 492.24 \\
\hline PB-III & 484.4 & 30.01 & 20.75 & 9.05 & 45.76 & 0.294 & 381.88 \\
\hline PB-IV & 816.7 & 21.11 & 17.78 & 6.9 & 34.02 & 0.264 & 205.79 \\
\hline CD & & & & & & & \\
\hline Site & NS & NS & 2.64 & 1.25 & NS & 0.024 & NS \\
\hline P.B. & 149.22 & 6.34 & 3.05 & 1.45 & 14.49 & NS & 157.24 \\
\hline & NS & 10.98 & NS & 2.51 & NS & 0.047 & NS \\
\hline
\end{tabular}


Figure.1 Density, basal area and growing stock performance young, medium and matured crop at site and PBs level

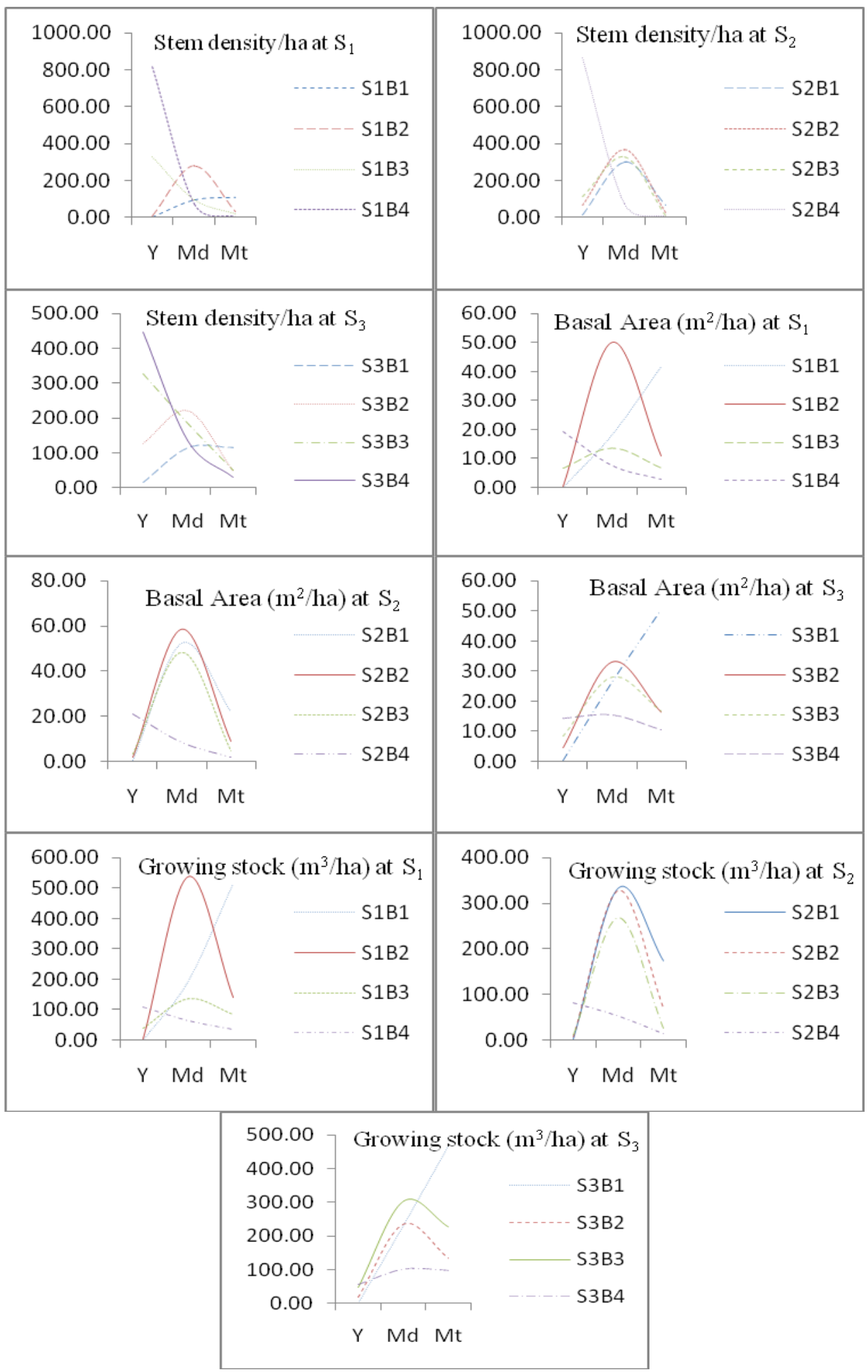

Note: Y- Young Crop (0-30 cm): Md-Medium Crop (30-60 cm): Matured Crop (> $60 \mathrm{~cm})$ 
Stem density (N/ha) of stand at P B s level approves the principle of allotment of crop to different PBs as per the crop age. PBIV being a regenerated block obviously supports more stems per unit area. Site quality, biophysical rate of seed dispersal, level of disturbance, stage of succession, altitude level (Chandra et al., 1999; Dzwonko and Loster, 2000) and stand management practices are other causes supporting the stocking level in this regard (Slik et al., 2010). Density-diameter distribution of deodar in the current study showed missing number of smaller and larger trees is worth to consider (Figure 1) that approves the similar results reported by Adhikari et al., (1996) at and around Nainital from Central Himalayan region also, study reported by Kaushal et al., (1996) in mixed deodar forest from dry temperate zone of north-west Himalayas recorded deodar tree density range as 350- 800 trees/ha. proved the current study reports (Fig. 1).

Mean diameter at breast height under the current investigation shows an increasing order of $\mathrm{DBH}$ from young crop to mature crop indicated that the tree growth is influenced by two opposing factors i.e., firstly the positive component associated with biotic potential, photosynthesis activity, absorption of nutrients, constructive metabolism etc., and secondly the negative component representing the restraints imposed by competition, limiting resources, stress, respiration and aging factors, which results in sigmoid shape of tree growth Kozlowaski (1971). study reported by Popoola (2012) that, DBH and tree height exhibits increasing trend with decreasing plant density as trees with close neighbor in all sides maintain small crown ratio and eventually slow in diameter growth. This observation holds good for diameter performance in current study where smaller diameter trees with higher stem density were found in PBIV and higher diameter trees in PBI with less stocking. More so the spacing in matured stand is not a constraint hence no limitations for diameter expansion compare to crowded stand where the available space is upward only. The diameter increment found to be pronounced with the availability of plenty of sunlight and moisture that results in wider annual rings (Stoddard, 1968). As per the yield table the mean diameter increases with increase in crop age. The same has been observed in PBI having big size, matured individuals with presence of exploitable girth than regenerated block- PBIV having young age crop. More so, in tall canopy trees fragmentation represents gradual incapability of the plant to replace dead structures and maintain optimal diameter growth rate (Genet et al., 2010) which could be the reason of diameter variation in different $\mathrm{PBs}$ under different sites. The good soil depth and less disturbance compared to other sites as observed during study period may be added substantiation for significant diameter performance at site level $\left(\mathrm{S}_{3}\right)$ as stem diameter is among the most sensitive character traits in trees likely to be affected by local environmental stresses (Dobbertin, 2005).

Regarding tree height differentiation at stand level, presence of different densities in different sites and PBs in current study indicates the level of competition with neighbor by individuals resulting differentiated use of vertical space. The significant performance of height at site and interaction level for $S_{3}$ and $S_{3} B_{1}$ in the current study may be because of this. This finding is in line with Gawali (2014) for $C$. pentandra. Also, the varying pattern of crown size with respect to density indicates the differential level of light requirements in these stands (Jack and Long 1991). The dominant and codominant trees with greater competitive vigor enjoy the available free space in top layer and harness the benefit of light increment apart from the trees on good site quality grow taller 
at faster rate than on poor ones (Avery and Burkhart, 1983). Further, study demands self thinning and managed thinning response for height growth at stand level in future.

The variation in mean basal area /ha was however in accordance with the stage of growth (Figure 1). In different PBs (Chaturvedi and Khanna 1982) with slight variation in PBIV and PBIII which might be due to non removal of over matured trees. Similar studies have been carried out by Kumar (2013) in deodar forest of Chail region in Himachal Pradesh. In comparison of study of Bhat et al., (2002) for the growing stock variations in different deodar forests of Garhwal Himalayas, which reported highest total basal cover (TBC) $(60.5424+$ or- 4.6362 $\left.\mathrm{m}^{2} / \mathrm{ha}\right)$ and minimum density (313 + or- 23.44 trees/ha) at in Dewarkhal area in Uttarkashi District is comparable for PBI basal area and density performance. The form factor of deodar stand showed greater significant variation at both site and their interaction level with minimum taper at site level $\mathrm{S}_{2}$ (0.219) followed by $S_{3}(0.258)$ and $S_{1}(0.343)$ in a manner that $S_{1}$ and $S_{2}$ significantly vary with each other. In site $S_{3}$, height and crown length was comparatively higher than $S_{1}$, is an indicator of good performance of form factor the results in accordance with the study of Singh (1976).

As the mean $h_{1}$ values were found to be consistently increasing with values from young crop to mature crop suggests the increase in diameter that does fall in line with the findings of Singh 2004 for deodar, Bhardwaj et al., (2001a) for Populus deltoids and Kumar (2009) for Acrocarpus fraxinifolius. Also, overall height $\left(\mathrm{H}_{1}\right)$ in all PBs remained high at $S_{1}$ due to smaller crown length as compared to $S_{3}$ and $S_{2}$. The growing stock (total stem volume/ha) variation at site level and their interaction levels were nonsignificant, but more average values were obtained in $\mathrm{S}_{3}$ is indicative of better growth performance and the higher growing stock in PBIV and PBIII (Figure 1). The higher growing stock in PBIV and PBIII in different sites was due to the presence of trees of higher diameter classes which otherwise were required to be removed for better growth of stock.

It is concluded that the density (N/ha) of deodar stand showed a regular increasing pattern with values 277.8, 390,484.4 and 816.7 N/ha under PBI, II, III and IV. Being a regenerated block PBIV showed highest numbers of total stems/ha at all the sites in comparison to matured PBI broadly approved the conventional crop allotment in PBs as per the crop age. Density variation both at younger and matured crop, was due to delayed regeneration felling, poor conversion of saplings to established individuals and degree of competition also shows its tendency to move towards even aged character. The irregular stocking prevails wherein middle aged crop found to be comparatively stable indicates the devoid of silvical treatments due to existing ban on green felling. Mean diameter increases with increase in crop age as $21.11 \mathrm{~cm}$ in PBIV 30.01 in PB III $44.64 \mathrm{~cm}$ in PBII and $57.37 \mathrm{~cm}$ in PBI. Also, suggests good competitive vigor, available spacing, level of disturbance, stage of growth and soil depth conditions for diameter variation. Further, mean tree height (m) vary significantly at site and PBS level with shown significant variation for different site and PBs with maximum value at S3 $(26.67 \mathrm{~m})$ and in PBI (31.88 m). Presence of different densities in different sites and PBs in indicates the level of competition with neighbor resulting differentiated use of vertical space with varying crown size generated differential level of light requirements. The highest basal area/ha was reported at S3 $(56.38 \mathrm{~m} 2 / \mathrm{ha})$ at site level and (70.95 $\mathrm{m} 2 / \mathrm{ha})$ in PBI respectively. This variation in mean basal area 
/ha was however in accordance with the stage of growth in different PBs with slight variation in PBIV and PBIII which might be due to non removal of over matured trees. Overall, maximum basal area was contributed from middle diameter classes. The form factor showed greater significant variation at both site and their interaction level with minimum taper at $S_{2}(0.219)$ and in $S_{2} B_{2}(0.207)$. The $\mathrm{H}_{1}$ reported increased value with increase in diameter where, overall height $\left(\mathrm{H}_{1}\right)$ in all PBs remained high at $S_{1}$ due to smaller crown length as compared to $S_{3}$ and $S_{2}$. The growing stock of deodar perform in descending order where $\mathrm{PBI}>\mathrm{PBII}>\mathrm{PBIII}>\mathrm{PBIV}$ respectively.

\section{References}

Adhikari B S, Dhaila Seema and Rawat Y S (1996). Density-diameter (D-D) distribution curve under exposed and unexposed areas at and around Nainital, Central Himalaya (U.P.). Indian Forester. 122(6): 520-522.

Anonymous (1985). Report on forest resources of Shimla, Rohru and Chopal forest divisions of Himachal Pradesh. FSI (N-Zone), MoEF. GOI: 94-95.

Assmann E (1970). The principles of forest yield study. New York: Pergamon Press. 506p.

Avery T E. and Burkhart H E (1983). Forest Measurements. New York: McGraw Hill. 290p.

Bhardwaj S D, Panwar P and Gautam S (2001a). Biomass production potential and nutrient dynamics of Populus deltoides under high density plantations. Indian Forester. 127(2): 144-153.

Bhatt A, Sharma C M and Khanduri V P (2002). Growing stock variations in different Cedrus deodara forests of Garhwal Himalaya. Indian Forester.
128(8): 903-916

Bitterlich W (1984). The relaskop idea slough: Commonwealth Agricultural Bureaux. Farnham Royal, England. 242p.

Champion H G. 1935. Silvicultural research manual for use in India. Vol: The experimental manual. Government of India Press. Delhi. 110p.

Chandra P, Uniyal V K and Prakash C (1999).Structure of forest vegetation along an altitudinal gradient in the Valley of Flowers National Park and its vicinity. Western Himalaya. 7(1):60-69.

Chaturvedi A N and Khanna L S (1982). Forest Mensuration. International Book Distributors, Dehradun, India. 403p.

Dobbertin M (2005). Tree growth as indicator of tree vitality and of tree reaction to environmental stress: a review. European Journal of Forest Research. 124: 319-333.

Dzwonko Z and Loster S (2000). Syntaxonomy and phyto-geographical differentiation of the Fagus woods in the Southwest Balkan Peninsula. Journal of Vegetation Science. 11(5): 667-678.

FSI. 2013. State of Forest Report (2013). Forest Survey of India, Dehradun.

Gawali A (2014). Studies on growth and floss yield of Ceiba pentandra (L) Gaertn. stands in sub humid tropics, Asian Journal of Plant Science and Research. 4(4): 37-39.

Genet H Breda and Dufrene N E (2010). Age related variation in carbon allocation at tree and stand scales in beech (Fagus sylvatica L.) and sessile oak (Quercus petraea (Matt.) Liebl.) using a chronosequence approach. Tree Physiology. 30: 177-192.

GOI (2008). National Action Plan on Climate Change. PM Council on Climate 
Change, GoI, New Delhi.

Helms J A.(1998).(ed). The dictionary of Forestry. Society of American Foresters. Bethesda, MD, USA.

Ishii Hiroaki T, Tanabe Shin-ichi and Hiura Tsutom (2004). Exploring their relationships among canopy structure, stand productivity and biodiversity of temperate forest ecosystems. Forest Science. 50(3): 342-355.

Jack S B. and Long J N (1991). Analysis of stand density effects on canopy structure: a conceptual approach. Trees Structure and Function. 5(1): 44-49

Joshi, P.K., S. Singh, S. Agarwal and P.S. Roy (2001). Forest cover assessment in western Himalayas, Himachal Pradesh using IRS 1C/1D WiFS data. Curr Sci., 80: 941-947

Kaushal R, Bhandari A R, Sharma J C and Tripathi D (1996). Tree productivity in north-west Himalayas: deodar tree productivity in dry temperate zone of north-west Himalayas. Indian Journal of Forestry. 19(3): 258-263.

Kozlowaski T T (1971). Growth and development of trees. Academic Press, New York. 443p.

Kumar Rakesh (2013). Studies on plant biodiversity of Chail wildlife sanctuary in Himachal Pradesh. M.Sc.
Thesis, Dr. Y. S. Parmar University of Horticulture and Forestry, Nauni, Solan, H.P., India. 83p.

Kumar Suresh (2009). Study of growth characteristics of Acrocarpus fraxinifolius Wight and Arn. under mid hill conditions of Himachal Pradesh. M.Sc. Thesis, Dr. Y. S. Parmar University of Horticulture and Forestry, Nauni, Solan, H.P., India. 95p.

Popoola F S and Adesoy P O (2012). Crown ratio models for Tectona grandis (Linn. f) stands in Osho forest reserve, Oyo state, Nigeria. Journal of Forest Science. 28(2): 63-67.

Pressler M (1865). Das Gesetz der stambidung. Leipzig. 153p.

Singh S P (1976). Stem standard timber form factor of some Indian conifers. IndianForester. 102(11): 747-760.

Slik J W, Shin - Ichiro Aiba S I, Brearley F QCannon C H, Forshed O, Kitayama $\mathrm{K}$ (2010). Environmental correlates of tree biomass, basal area, wood specific gravity and stem density gradients in Borneo's forests. Global Ecology and Biogeography. 19: 50-60.

Stoddard Charles H (1968). Essentials of forestry practice. 2nd edition. The Ronald Press Company, New York. 362 p.

\section{How to cite this article:}

Prahlad, V.C. 2018. Stand Structure and Growth Pattern of Deodar (Cedrus deodara Roxb. Loud) Forests of Western Himalaya (India). Int.J.Curr.Microbiol.App.Sci. 7(07): 1737-1745. doi: https://doi.org/10.20546/ijcmas.2018.707.206 